\title{
RATER MODEL: AN ASSESSMENT AMONG HEALTH INSURANCE PATIENTS
}

\author{
K N Priya \\ Lecturer, Sri Ramachandra Faculty of Management Sciences, Sri Ramachandra Institute of \\ Higher Education and Research, Chennai, Tamilnadu, India \\ Dr. A Bhoomadevi \\ Associate Professor, Sri Ramachandra Faculty of Management Sciences, Sri Ramachandra \\ Institute of Higher Education and Research, Chennai, Tamilnadu, India
}

\begin{abstract}
The purpose of the study is to assess the service quality among insured patients using the RATER model i.e., responsiveness. Assurance, Tangibility, Empathy and Reliability. Researchers used modified questionnaires to collect the data. The respondents of the study consisted of 75 patients who were hospitalized under private health insurance. There is no difference between expectation and perception of service quality among health insurance patients. The expected service was provided by the service provider.
\end{abstract}

Key words: RATER, insured patients, service quality.

Cite this Article: K N Priya and A Bhoomadevi, RATER model: An Assessment among Health Insurance patients, International Journal of Management, 11(12), 2020, pp. 2430-2437.

http://iaeme.com/Home/issue/IJM?Volume $=11 \&$ Issue $=12$

\section{INTRODUCTION}

There is a significant expansion in the service sector of the global economy. The formation of consumers' expectations is influenced by word-of-mouth communication, past experiences, personal needs, and what the staff communicates to the customer.One of the most important concerns for the healthcare industry is process improvement. Hospitals are working towards utilising modern technological equipment to deliver the best quality care. In Spite of improvement in the effectiveness of the services, the satisfaction of patients remains as a challenge for providers. Philip Kotler and Gary Armstrong defined the term 'service quality' as" it is the ability of a service firm to hang on its customer". It refers to the patient's comparison of service expectations as it relates to the service providers. The service provider should be able to meet out the patient requirements and it should be fulfilled. Once it is done successfully, the patient will become loyal, increase in cash flow and there is no need for any marketing strategies to promote the services. There are various models available for measuring service quality such 
as RATER which is widely used by the researchers, Mystery shopping, Post service rating, Follow-up survey, In-App survey, Customer effort score, social media monitoring, and Documentation analysis.

\section{THEORETICAL BACKGROUND}

Parasuraman et al., (1985) have framed a service quality model that can be often used in healthcare service quality evaluation. The five dimensions of SQ are the RATER model, $\mathrm{R}$ for Reliability - the capability to provide promised service in a confidential manner. A for Assurance - ability, and courtesy of the staff inspire confidence to patients. T for Tangibility Physical appearance, Modern equipment which is available in healthcare settings $E$ for Empathy - pay attention to each patient and caring provides to patients. R for Responsiveness eagerness to help patients and provide prompt service.

Rohini.R, Mahadevappa.B (2006) have conducted an empirical study on service quality in Bangalore hospitals. SERVQUAL score in Gap $5(-0.29)$ and positive score in Gap 1 (0.13). The expectations of patients on the service quality will be more than that of the management's perception.

Mehmet Pekkaya et al., (2017) conducted a study on the evaluation of healthcare service quality via the SERVQUAL scale. From the statistical analysis, it was found that the reliability dimension scored high, followed by responsiveness, empathy, assurance, and tangibles.

Zamil AM, Areiqat AY (2019) Patients' perception on service quality was important to measure the operations of service providers.

Owusu Kwateng Kwame et al., (2019) service quality delivery provided by private healthcare facilities was better than public healthcare facilities.

\section{DATA AND METHODOLOGY}

The study utilized cross sectional data from select private Multi-specialty hospitals. 75 patients were sampled with SERVQUAL instruments consisting of five variables. A quantitative method was used to collect data. The respondents were selected based on Judgemental sampling technique. The researcher approached the Health Insurance desk and received a census from the service provider and approached patients.

\subsection{Objectives}

To evaluate the expectation and perception of service quality among health insurance patients.

The data for the study were analysed by using the Statistical package for social sciences. The expectation and perception of respondents were evaluated.

\subsection{Hypothesis}

There exist differences in the expectation and perception of service quality among health insurance patients 


\section{RESPONDENT PROFILE}

Table 1 Age of respondents

\begin{tabular}{|c|c|c|}
\hline Age & Frequency & Percent \\
\hline$<30 \mathrm{yrs}$ & 29 & 38.7 \\
\hline $31-40 \mathrm{yrs}$ & 25 & 33.3 \\
\hline$>41 \mathrm{yrs}$ & 21 & 28.0 \\
\hline Total & 75 & 100.0 \\
\hline
\end{tabular}

Source: Primary data, computed using SPSS

The above table showed that $38.7 \%$ of the respondents were below 30 years, $33 \%$ of the respondents were the age group of $31-40$ years, and $28 \%$ of the respondents were above 41 years.

Table 2 Gender of respondents

\begin{tabular}{|c|c|c|}
\hline Gender & Frequency & Percent \\
\hline Male & 35 & 46.7 \\
\hline Female & 40 & 53.3 \\
\hline Total & 75 & 100.0 \\
\hline
\end{tabular}

Source: Primary data

The above table showed that $46.7 \%$ of the respondents were male patients and $40 \%$ of the respondents were female patients.

Table 3 Marital Status of respondents

\begin{tabular}{|l|c|c|}
\hline Marital Status & Frequency & Percent \\
\hline Married & 24 & 32.0 \\
\hline Unmarried & 31 & 41.3 \\
\hline Others & 20 & 26.7 \\
\hline Total & 75 & 100.0 \\
\hline
\end{tabular}

Source: Primary data

$32 \%$ of the patients were married and $31 \%$ patients were unmarried.

Table 4 Qualification of respondents

\begin{tabular}{|l|c|c|}
\hline Qualification & Frequency & Percent \\
\hline Graduation & 30 & 40.0 \\
\hline Post-graduation & 27 & 36.0 \\
\hline
\end{tabular}


K N Priya and A Bhoomadevi

\begin{tabular}{|l|c|c|}
\hline Professional Degree & 18 & 24.0 \\
\hline Total & 75 & 100.0 \\
\hline
\end{tabular}

Source: Primary data, computed using SPSS

The above table showed that $40 \%$ of the respondents were graduated patients, $36 \%$ of the respondents were post graduated and $24 \%$ of the respondents were professional degree holders.

Table 6 Occupation of respondents

\begin{tabular}{|l|c|c|}
\hline Occupation & Frequency & Percent \\
\hline Employed & 12 & 16 \\
\hline Self employed & 19 & 26 \\
\hline Government & 15 & 20 \\
\hline Retired & 18 & 24 \\
\hline Others & 11 & 15 \\
\hline Total & 75 & 100 \\
\hline
\end{tabular}

Source: Primary data, computed using SPSS

The above table showed that $16 \%$ of the respondents were employed, $26 \%$ of the respondents were self employed, $24 \%$ of the respondents were retired

Table 7 Expectation of the Service among Health Insurance patients

\begin{tabular}{|l|l|l|l|}
\hline \multicolumn{2}{|c|}{ Varirables } & \multicolumn{1}{c|}{$\begin{array}{c}\text { Std. } \\
\text { Deviation }\end{array}$} \\
\hline Service Reliability & Mean & 4.147 & 0.800 \\
\hline The hospital should provide service as promised & 3.947 & 0.787 \\
\hline Hospital service should be effective & 4.027 & 0.822 \\
\hline Diagnoses should be made correctly at the first attempt & 4.027 & 0.805 \\
\hline Doctors and employees should provide service at the promised time & 3.880 & 0.805 \\
\hline Patients' records should be maintained correctly & \multicolumn{2}{|l|}{} \\
\hline Responsiveness & 4.080 & 0.801 \\
\hline $\begin{array}{l}\text { Doctors and employees should communicate well with patients while } \\
\text { providing service }\end{array}$ & 4.107 & 0.815 \\
\hline Service should be provided promptly when you need it & 3.933 & 0.827 \\
\hline Doctors and employees should be willing to provide effective service & 3.920 & 0.834 \\
\hline Patients should trust a doctor while receiving the service & \\
\hline
\end{tabular}


RATER model: An Assessment among Health Insurance patients

\begin{tabular}{|l|l|l|l|}
\hline Assurance & 3.987 & 0.846 \\
\hline Hospital employees should be willing to help patients & 4.053 & 0.884 \\
\hline Patients should feel safe while receiving the treatment & 3.987 & 0.744 \\
\hline Hospital staffs should always be courteous in all circumstances & 4.200 & 0.854 \\
\hline $\begin{array}{l}\text { Hospital employees should be knowledgeable to answer patients' } \\
\text { questions. }\end{array}$ & 4.053 & 0.837 \\
\hline Empathy & 4.040 & 0.796 \\
\hline Doctors and employees should give patients individual attention & 4.000 & 0.854 \\
\hline Hospital staffs should always act in a professional manner & \multicolumn{2}{|l|}{} \\
\hline Doctors and employees should keep rapport with the patient's best interest & 3.840 & 0.823 \\
\hline Tangibles & 4.000 & 0.870 \\
\hline The hospital should be well equipped with modern instruments & 4.080 & 0.801 \\
\hline Physical facilities of the health care unit should be visually appealing & 3.933 & 0.811 \\
\hline The hospital should provide a neat and clean environment & \\
\hline Hospital laboratories and related materials should be appealing & \\
\hline
\end{tabular}

Source: Primary data, computed using SPSS

With respect to expectation of service reliability the highest mean value of 4.147 was recorded for the statement hospital should provide service as promised. Record maintenance was of lesser importance among the health insurance patients as it was recorded the lowest mean value of 3.880. With respect to responsiveness the highest mean value of 4.107 was recorded for the statement service should be provided promptly. The highest mean value of 4.200 was derived for the statement hospital employees should be knowledgeable to patient queries and least score was recorded for the employees should be courteous in all circumstances and employees should be willing to help patients. The highest mean value of 4.053 was recorded for the statement doctors and staff should provide individual attention to patients. Finally, with reference to tangibility the highest mean value of 4.080 was recorded for a neat and clean environment in the hospital.

Table 8 Perception of the Service among Health Insurance patient

\begin{tabular}{|c|c|c|}
\hline Variables & Mean & $\begin{array}{l}\text { Std. } \\
\text { Deviation }\end{array}$ \\
\hline \multicolumn{3}{|l|}{ Reliability } \\
\hline Does the hospital provide service as promised & 3.987 & 0.814 \\
\hline Do you consider the hospital service as effective & 4.000 & 0.788 \\
\hline $\begin{array}{l}\text { Do you consider that diagnoses were made correctly at first attempt } \\
\text { whenever you used the service }\end{array}$ & 3.947 & 0.837 \\
\hline
\end{tabular}


K N Priya and A Bhoomadevi

\begin{tabular}{|c|c|c|}
\hline Are you satisfied that doctors provide service at the promised time & 4.053 & 0.820 \\
\hline Do you believe that patients' records are maintained correctly & 4.053 & 0.837 \\
\hline \multicolumn{3}{|l|}{ Responsiveness } \\
\hline Does the doctor communicate well with you when providing the service & 3.840 & 0.772 \\
\hline Are you satisfied that the service is provided promptly when you need it & 3.920 & 0.882 \\
\hline Do you find doctors and employees willing to provides effective service & 4.067 & 0.794 \\
\hline $\begin{array}{l}\text { Do doctors and employees make sure that you trust him/her before } \\
\text { providing the service }\end{array}$ & 4.053 & 0.804 \\
\hline \multicolumn{3}{|l|}{ Assurance } \\
\hline $\begin{array}{l}\text { Are you satisfied that the hospital employees are willing to help whenever } \\
\text { you need }\end{array}$ & 3.893 & 0.798 \\
\hline Do you feel safe while receiving the treatment & 3.947 & 0.804 \\
\hline $\begin{array}{l}\text { Are you satisfied that hospital staffs are always courteous in all } \\
\text { circumstances }\end{array}$ & 4.027 & 0.753 \\
\hline $\begin{array}{l}\text { Have you always found health hospital employees knowledgeable to answer } \\
\text { your questions }\end{array}$ & 4.053 & 0.837 \\
\hline \multicolumn{3}{|l|}{ Empathy } \\
\hline Do your doctors and employees give you individual attention & 3.933 & 0.890 \\
\hline Do you consider that hospital staffs always act in a professional manner & 4.027 & 0.822 \\
\hline $\begin{array}{l}\text { Are you satisfied that doctors and employees keep rapport with your best } \\
\text { interest }\end{array}$ & 4.027 & 0.838 \\
\hline \multicolumn{3}{|l|}{ Tangibles } \\
\hline Are you satisfied that the hospital is well equipped with modern instruments & 3.800 & 0.771 \\
\hline Do you find the physical facilities of the health care unit visually appealing & 4.013 & 0.830 \\
\hline Are you satisfied that the hospital provides a neat and clean environment & 4.080 & 0.882 \\
\hline Do you consider hospital laboratories and related materials are appealing & 3.973 & 0.753 \\
\hline
\end{tabular}

Source: Primary data, computed using SPSS

With reference to perception of service reliability, the highest mean value 4.053 was recorded for the statement doctors provide service as promised and patient records were maintained properly. The highest mean value of 4.067 was recorded for the statement doctors and employees in willingness to provide service. The lowest mean value of 3.933 was recorded for doctors and employees provided individual attention. With respect to tangibility the least score of 3.800 was recorded for the statement well equipped modern equipment in the hospital. The lowest mean value of 3.800 was recorded for the statement hospital is well equipped with modern instruments. 
RATER model: An Assessment among Health Insurance patients

Table 9 Comparison between Expectation and Perception of the Service quality among Health Insurance patient

\begin{tabular}{|c|c|c|c|c|c|c|c|}
\hline & & $\mathrm{N}$ & Mean Rank & Sum of Ranks & $\mathrm{U}$ & Z & Sig \\
\hline \multirow[t]{3}{*}{ Reliability } & Expectation & 75 & 74.70 & 5602.50 & \multirow[t]{3}{*}{2752.500} & \multirow[t]{3}{*}{-0.228} & \multirow[t]{3}{*}{0.819} \\
\hline & Perception & 75 & 76.30 & 5722.50 & & & \\
\hline & Total & 150 & & & & & \\
\hline \multirow[t]{3}{*}{ Responsiveness } & Expectation & 75 & 77.93 & 5845.00 & \multirow[t]{3}{*}{2630.000} & \multirow[t]{3}{*}{-0.701} & \multirow[t]{3}{*}{0.483} \\
\hline & Perception & 75 & 73.07 & 5480.00 & & & \\
\hline & Total & 150 & & & & & \\
\hline \multirow[t]{3}{*}{ Assurance } & Expectation & 75 & 80.89 & 6067.00 & \multirow[t]{3}{*}{2408.000} & \multirow[t]{3}{*}{-1.546} & \multirow[t]{3}{*}{0.122} \\
\hline & Perception & 75 & 70.11 & 5258.00 & & & \\
\hline & Total & 150 & & & & & \\
\hline \multirow[t]{3}{*}{ Empathy } & Expectation & 75 & 76.99 & 5774.50 & \multirow[t]{3}{*}{2700.500} & \multirow[t]{3}{*}{-0.430} & \multirow[t]{3}{*}{0.667} \\
\hline & Perception & 75 & 74.01 & 5550.50 & & & \\
\hline & Total & 150 & & & & & \\
\hline \multirow[t]{3}{*}{ Tangibles } & Expectation & 75 & 75.91 & 5693.50 & \multirow[t]{3}{*}{2781.500} & \multirow[t]{3}{*}{-0.119} & \multirow[t]{3}{*}{0.906} \\
\hline & Perception & 75 & 75.09 & 5631.50 & & & \\
\hline & Total & 150 & & & & & \\
\hline
\end{tabular}

Source: Primary Data, Computed using SPSS

Null hypothesis is rejected. There is no difference between expectation and perception of service quality among health insurance patients. The hospital provides effective service as expected by the patients.

\section{CONCLUSION \& IMPLICATIONS}

It is concluded that there is no difference in expectation and perception of the service quality in the hospital. The hospital is meeting out the requirements and expectations of the patients. The hospital can focus on strategies on patient loyalty and customer retention.

\section{ACKNOWLEDGEMENT}

I would like to thank Prof. Mohammad Ishfaq, MBA, MSc., PhD (LSE, London)

Head of Finance Department, College of Business, Rabigh - King Abdulaziz University, KSA for sharing the questionnaire. 


\section{REFERENCES}

[1] Mehmet Pekkaya, Znur Pulat Imamoglu, Hayriye Koca (2019) International Healthcare Management, Vol 12, No.4, 340 - 347

[2] Owusu Kwateng, Kwame Lumor, Rita Acheampong, Florence Ofosuaa (2019) Service quality in private and public hospitals; A comparative study on patient satisfaction, International Journal of Healthcare Management, Nov 2019, Vol.12, Issue - 4, P -251- 258

[3] Parasuraman A, Zeithaml VA, Berry LL. A conceptual model of service quality and its implications for future research. J Mark. 1985;49(3):44

[4] Rohini.R, Mahadevappa.B (2006) Service Quality in Bangalore Hospitals - An empirical study, Journal of Services Research, Volume 6, Number 1

[5] Zamil AM, Areiqat W. The impact of health service quality on patients' satisfaction over private and public hospitals in Jordan: a comparative study. International Journal for Marketing studies 2012; 4(1): $123-137$

[6] Zeithaml VA Parasuraman A Berry 1990 Service leadership spells profits in:Delivering Quality Service; Balancing Customer Perceptions andExpectationsNew YorkThe Free Press 